\title{
Isolation, Identification, and Characterization of a Keratin-degrading Bacterium Chryseobacterium sp. P1-3
}

\author{
Sung-Jun Hong • Gun-Seok Park • Byung Kwon Jung • Abdur Rahim Khan • \\ Yeong-Jun Park • Chang-Hyun Lee "Jae-Ho Shin* (D)
}

Received: 10 April 2015 / Accepted: 29 June 2015 / Published Online: 30 September 2015

(C) The Korean Society for Applied Biological Chemistry 2015

\begin{abstract}
In this study, a keratin-degrading bacterium was isolated from soil contaminated with feather waste. The isolated strain was identified as Chryseobacterium sp. P1-3 on the basis of the 16S rRNA gene sequence alignment. Chryseobacterium sp. P1-3 is currently used in various biotechnological applications (e.g., in the hydrolysis of poultry feathers). It hydrolyzed the feather meal within 2 days and possesses a high level of keratinase activity $(98 \mathrm{U} / \mathrm{mL})$. The keratinase, partially purified from this strain, prefers casein as a substrate and shows optimal activity at a temperature of $30^{\circ} \mathrm{C}$ and at a $\mathrm{pH}$ of 8.0.
\end{abstract}

Keywords Chryseobacterium sp. · isolation · keratin

\section{Introduction}

Keratins are ubiquitously present in animal bodies. The livestock industry is a key producer of keratinous wastes, the disposal of which is exceedingly difficult (Joshi et al., 2007). Several million tons of these wastes are generated annually around the world. At present, various physicochemical and bacteriological methods are being used to convert feathers into feather meal, which is then used as animal feed. Therefore, it would help livestock producers greatly, if this feedstuff were enriched in proteins and essential

S.-J. Hong · G.-S. Park · B. K. Jung · A. R. Khan · Y.-J. Park · C.-H. Lee · J.-H. Shin

School of Applied Biosciences, College of Agriculture and Life Sciences, Kyungpook National University, Daegu 702-701, Republic of Korea

*Corresponding author (J.-H. Shin: jhshin@knu.ac.kr)

This is an Open Access article distributed under the terms of the Creative Commons Attribution Non-Commercial License (http://creativecommons. org/licenses/by-nc/3.0/) which permits unrestricted non-commercial use, distribution, and reproduction in any medium, provided the original work is properly cited. amino acids. However, the processing methods necessary for producing enriched livestock feedstuff necessitate the investment of large amounts of energy. Additionally, the finished product lacks digestibility and contains components of low quality (Wang and Parsons, 1997; Nam et al., 2002).

Keratin is the most abundant protein present in feathers, horns, skin, hair, hooves, and wool. It harbors large amounts of the sulfur-containing amino acid cysteine and exhibits $\alpha$-helical or $\beta$ sheet structures (Bockle et al., 1995). Keratin, in its native state, cannot be easily degraded by commonly occurring proteases such as trypsin, papain, and pepsin. However, it can be efficiently degraded by the keratinase produced by microorganisms (Onifade et al., 1998). In recent years, several keratinases from various microorganisms such as Chryseobacterium (Riffel et al., 2007), Bacillus (Macedo et al., 2005), thermophilic bacteria (Riessen and Antranikian, 2001), and fungi (Gradišar et al., 2000) have been purified and characterized. Thus, keratinase has an important role in the bioremediation of keratinous wastes produced by the livestock, textile, and leather industries. Such a large-scale bioremediation can be achieved through the development of environment-friendly processes (SHIH, 1993). The keratinasemediated enzymatic hydrolysis can be used to convert the insoluble keratin into livestock feedstuff, fertilizers, films, and glues (Gupta and Ramnani, 2006). In addition, keratinase has also been found to be incredibly useful to the cosmetics and pharmaceutical industries (Brandelli, 2008).

Members of the genus Chryseobacterium produce enzymes with strong proteolytic activities (Vandamme et al., 1994). We have isolated a new keratin-degrading bacterium, Chryseobacterium $\mathrm{sp}$. P1-3. The isolated strain is able to degrade animal feathers as well as other keratin-containing materials. The extracellular keratinase produced by this bacterium, could potentially benefit the environment and the industry (Riffel et al., 2007). In addition, the keratinolytic product generated by this enzyme could be utilized for producing organic fertilizers and amino acids (Riffel et al., 2003). 


\section{Materials and Methods}

Isolation of the keratin-degrading bacterium. The keratindegrading bacterium was isolated from soil contaminated with feather waste at a poultry processing facility in Korea. For the first screening, we used $100 \mathrm{~mL}$ of the feather meal medium $(1 \%(\mathrm{w} / \mathrm{v})$ feather meal, $0.05 \% \mathrm{NaCl}, 0.05 \% \mathrm{NH}_{4} \mathrm{Cl}, 0.03 \% \mathrm{KH}_{2} \mathrm{PO}_{4}, 0.03 \%$ $\mathrm{K}_{2} \mathrm{HPO}_{4}, 0.01 \% \mathrm{MgCl}_{2} \cdot 6 \mathrm{H}_{2} \mathrm{O}, 0.01 \%$ yeast extract, $\mathrm{pH} 7.2$ ). Five grams of the soil was suspended in the feather meal medium. After an incubation period of 7 days, a loopful of the suspension was streaked onto a skim milk agar plate (1.0\% skim milk, $0.03 \%$ $\mathrm{K}_{2} \mathrm{HPO}_{4}, 0.03 \% \mathrm{KH}_{2} \mathrm{PO}_{4}, 0.01 \% \mathrm{Na}_{2} \mathrm{CO}_{3}, 1.5 \%$ agar, $\mathrm{pH} 7.2$ ) in order to obtain isolated colonies. The isolates that produced clear zones on this medium were selected (Zerdani et al., 2004). This method was used as an initial screening for the isolation of keratin-degrading strains.

Identification of the keratin-degrading bacterium. The isolated strain was grown overnight in $3 \mathrm{~mL}$ of the nutrient broth medium at $30^{\circ} \mathrm{C}$ at $200 \mathrm{rpm}$. Genomic DNA was extracted from the cells by using the Genomic DNA prep kit (Bioneer, Korea), according to the manufacturer's instruction. Polymerase chain reaction (PCR) amplification was performed using the Biometra TGradient PCR (Biometra, Germany), which was followed by the DNA sequencing of the corresponding 16S rRNA gene. The universal primers 27F (5'-AGA GTT TGA TCC TGG CTC AG-3') and 1492R (5'-GGC TAC CTT GTT ACG ACT T-3') were used (Weisburg et al., 1991) during this procedure. The PCR mixture contained $5 \mu \mathrm{L}$ of $5 \mathrm{X}$ PrimeSTAR buffer, $4 \mu \mathrm{L}$ of $2.5 \mathrm{mM}$ dNTP mix, $1 \mu \mathrm{L}$ of $10 \mathrm{pM}$ primers, $1 \mu \mathrm{L}$ of genomic DNA template $(10 \mathrm{ng} / \mu \mathrm{L})$, and $1.25 \mathrm{U}$ of PrimeSTAR HS DNA Polymerase (TaKaRa, Japan) in a final reaction volume of $50 \mu \mathrm{L}$. The PCR conditions were as follows: initial denaturation at $98^{\circ} \mathrm{C}$ for $2 \mathrm{~min}$, followed by 30 cycles of denaturation at $95^{\circ} \mathrm{C}$ for $30 \mathrm{sec}$, primer annealing at $55^{\circ} \mathrm{C}$ for $30 \mathrm{sec}$, and extension at $72^{\circ} \mathrm{C}$ for $90 \mathrm{sec}$. The amplified PCR products were analyzed by $0.8 \%(\mathrm{w} / \mathrm{v})$ agarose gel electrophoresis and purified using the AxyPrep ${ }^{\mathrm{TM}}$ PCR cleanup kit (Axygen, USA), according to the manufacturer's instructions. The sequencing of the amplified DNA fragments was performed by Solgent Co. (Korea). The 16S rRNA gene sequence was compared with the existing EzTaxon database to identify the corresponding species (Kim et al., 2012).

Phylogenetic analysis. A phylogenetic tree was constructed on the basis of the 16S rRNA gene sequence by using the neighborjoining algorithm and the p-distance model (Saitou and Nei, 1987) in MEGA ver. 5.2 (Tamura et al., 2011). The level of support for the phylogenies derived from the neighbor-joining algorithm was gauged by 1,000 bootstrap replicates. The percentage of replicates in which the associated taxa clustered together in the bootstrap analysis was shown near the sides of the branches (Felsenstein, 1985). The tree is drawn to scale, with branch lengths in the same units as those of the evolutionary distances used to infer the phylogenetic tree. All positions containing gaps and missing data were eliminated from the data sheet.

Degradation of chicken feathers. The degradation ratio of chicken feathers $(1 \%(\mathrm{w} / \mathrm{v}))$ was calculated by determining the dry weight of chicken feathers remaining in the culture medium at the end of the experiment. An outstanding media were removed by using a Whatman no. 2 filter paper and dried at $70^{\circ} \mathrm{C}$ for $24 \mathrm{~h}$ to analysis the degradation of that. The results were expressed as a function of the initial weight $(100 \%)$ and were calculated by comparing the dry weight of the residual chicken feathers before and after degradation (Cortezi et al., 2008).

Assay for crude keratinase. The protease assay was performed as per the method adopted by Kim et al. (2012). To evaluate the crude keratinase, the supernatant of cells grown in the feather meal medium was used. The reaction mixture contained $0.5 \mathrm{~mL}$ of the crude extracellular enzyme and $2.5 \mathrm{~mL}$ of a casein solution $(0.6 \%(\mathrm{w} / \mathrm{v})$ casein in $50 \mathrm{mM}$ Tris-Cl buffer, $\mathrm{pH} 7.0)$. This mixture was allowed to stand at $37^{\circ} \mathrm{C}$ for $20 \mathrm{~min}$, and the enzyme reaction was quenched with $2.5 \mathrm{~mL}$ of trichloroacetic acid $(50 \%(\mathrm{v} / \mathrm{v}))$. After centrifuging the solution at $12,000 \mathrm{rpm}$ for $20 \mathrm{~min}$, it was filtered with a Whatman no. 2 filter paper. To $1 \mathrm{~mL}$ of the filtrate (enzyme-substrate mixture), we added $2.5 \mathrm{~mL}$ of $0.55 \mathrm{M} \mathrm{Na}_{2} \mathrm{CO}_{3}$. To this mixture, we added $0.5 \mathrm{~mL}$ of the Folin-Ciocalteu phenol reagent and mixed the solution rapidly. After $30 \mathrm{~min}, 6 \mathrm{~mL}$ of distilled water was added, and the contents were again mixed thoroughly. The mixture was measured spectrophotometrically at $660 \mathrm{~nm}$ using UV 1800 spectrophotometer (Shimadzu, Japan) (Lowry et al., 1951). The presence of the liberated amino acids was detected using a blank control at $660 \mathrm{~nm}$, and the corresponding quantities were estimated with a standard L-tyrosine solution (10 $100 \mu \mathrm{M}$ ), using a spectrophotometer (Shimadzu, Japan). One protease unit $(\mathrm{U})$ was defined as the amount of enzyme that caused an increase of 0.01 unit in the absorbance of the sample at $660 \mathrm{~nm}$, relative to the control assessed under the same conditions. Influence of $\mathbf{p H}$ and temperature on enzyme activity. The influence of $\mathrm{pH}$ and temperature on the activity of the crude extracellular enzyme was assessed by varying one factor at a time while keeping the remaining factors constant. The optimal $\mathrm{pH}$ of this enzyme was in the range of $4.0-10.0$ at $30^{\circ} \mathrm{C}$. Citrate- $\mathrm{NaOH}$, sodium phosphate, and glycine- $\mathrm{NaOH}$ buffers were used in the $\mathrm{pH}$ ranges 4.0-6.0, 7.0-8.0, and 9.0-10.0, respectively. Likewise, the optimal temperature for the activity of the crude extracellular enzyme was determined by varying the temperature in the range of $20-60^{\circ} \mathrm{C}$ at a constant $\mathrm{pH}(\mathrm{pH} 8.0)$.

Statistical analysis. The means and standard errors were calculated for at least three different replicates. The statistical analysis was performed using GraphPad Prism ver. 5.0.

\section{Results and Discussion}

Isolation and identification of the keratin-degrading bacterium. Among the samples collected from the different sources, three samples yielded colonies on the agar plates containing minimal salt medium with skim milk as the only source of carbon and nitrogen. Evaluation of the keratinolytic activity in the culture supernatants of these colonies revealed one strain showing the 


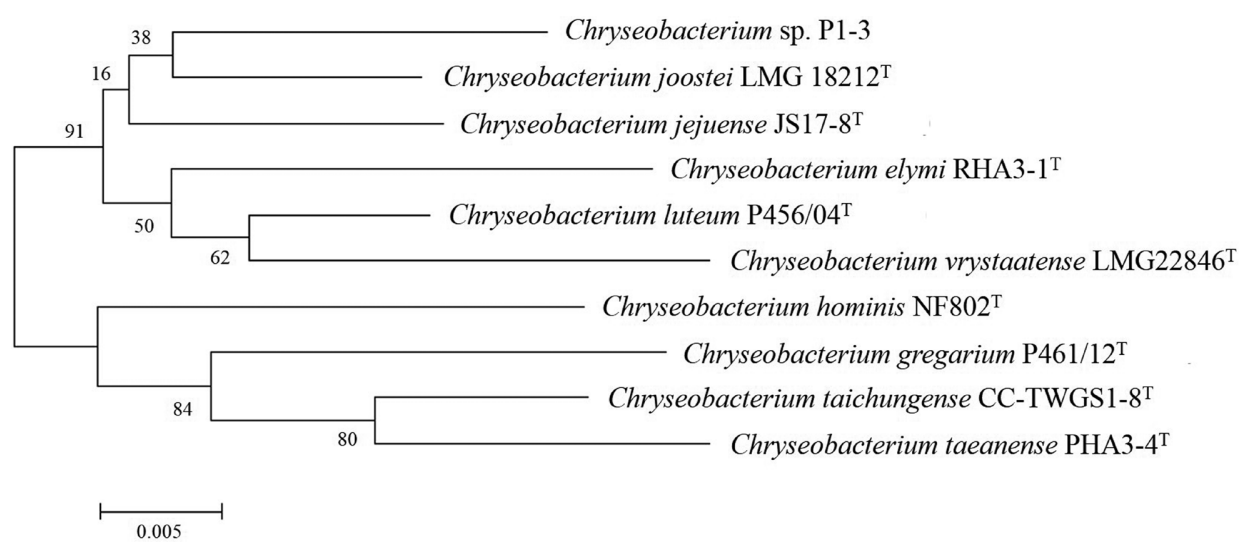

Fig. 1 A phylogenetic tree showing the genetic relationship between Chryseobacterium sp. P1-3 strain and the reference strains based on the 16S rRNA gene sequence analysis. The branching pattern was generated by the neighbor-joining method. The number on each branch indicates the bootstrap values based on 1,000 replicates.

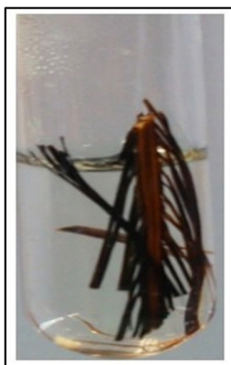

(A)

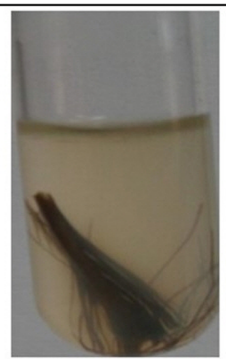

(B)

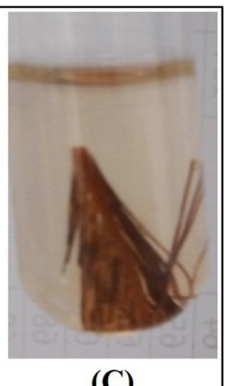

(C)
Fig. 2 Feather degradation by the Chryseobacterium sp. P1-3 after (A) 1 $\mathrm{h}$ and after (B) 7 days at a temperature of $30^{\circ} \mathrm{C}$, and (C) feather after 7 days at $30^{\circ} \mathrm{C}$ without Chryseobacterium sp. P1-3.

highest keratinolytic activity. This strain was isolated from soil contaminated with feather waste and was named as P1-3.

The 16S rRNA gene sequence of the isolated microorganism was sequence aligned and compared using the EzTaxon program. The isolated strain was identified as Chryseobacterium sp. P1-3. A phylogenetic tree of the isolated strain P1-3 was constructed (Fig. 1). The digits adjacent to the nodes correspond to the statistical frequency of the indicated species. The results of the homology assay showed that Chryseobacterium sp. P1-3 in the phylogenetic branch showed maximal similarity of $97.3 \%$ with the $C$. joostei strain LMG 18212 (Hugo et al., 2003) and a similarity of $96 \%$ with the $C$. jejuense strain JS17-8 (Weon et al., 2008). This strain was established as a Chryseobacterium species by the EzTaxon database. It is already known that the degradation of keratin is efficiently performed by gram-positive bacteria (Gupta and Ramnani, 2006). Moreover, some isolates of the Gram-negative Chryseobacterium sp. have already been described as good feather-degrading bacteria (Wang et al., 2008). The isolated strain showing high keratinolytic activity could be potentially used for various industrial processes.

Degradation of chicken feathers by using Chryseobacterium sp. P1-3. Degradation of chicken feathers by the isolated strain P1-3 was assessed by determining the percentage loss in the

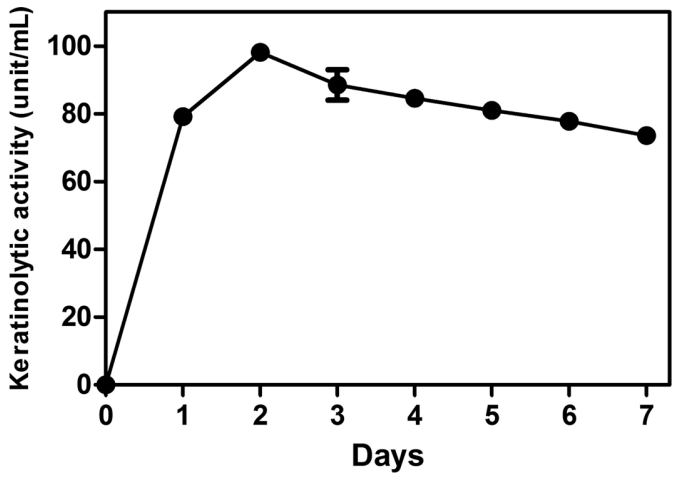

Fig. 3 Extracellular protease activity during the growth of the keratinolytic bacterium Chryseobacterium sp. P1-3 strain in chicken feather meal broth. Enzyme activity was measured using casein as the substrate. Each point represents the mean of three independent experiments.

weight of the feathers during the enzymatic treatment. After removing the bacteria from the feather strips, different microscopic changes were observed (data not shown). The percentage loss in the weight of the feathers increased significantly after 2 days of cultivation and went up to $65 \%$ after 7 days of cultivation (Fig. 2). However, the chicken feathers were not degraded completely by the isolated strain P1-3 owing to a relatively slower enzymatic reaction. (Corrêa et al., 2010; Jeong et al., 2010). In addition, incomplete degradation of chicken feathers by many other bacterial strains has been previously reported (Bach et al., 2011). Production of keratinase by using chicken feathers. The keratinase-producing Chryseobacterium sp. P1-3 strain was grown in a liquid minimal medium with $1 \%(\mathrm{w} / \mathrm{v})$ chicken feather serving as the major source of carbon and nitrogen. The production of keratinase was observed for 7 days. The highest quantity of keratinase was produced within 2 days of culture. The optimal enzymatic activity was $98 \mathrm{U} / \mathrm{mL}$, which decreased 2 days later (Fig. 3). Chryseobacterium strains often produce keratinases at mesophilic temperatures (Venter et al., 1999; Chaudhari et al., 2013). Although these conditions were considered satisfactory for 
(A)

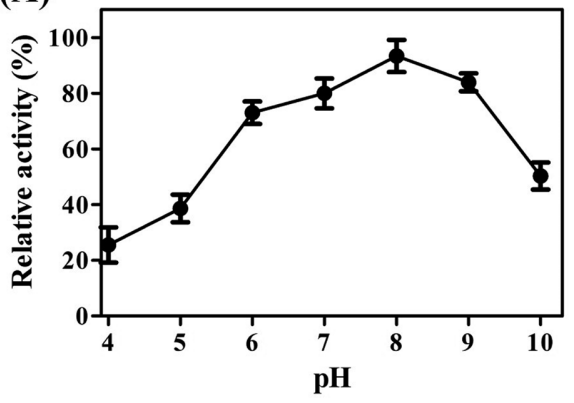

(B)

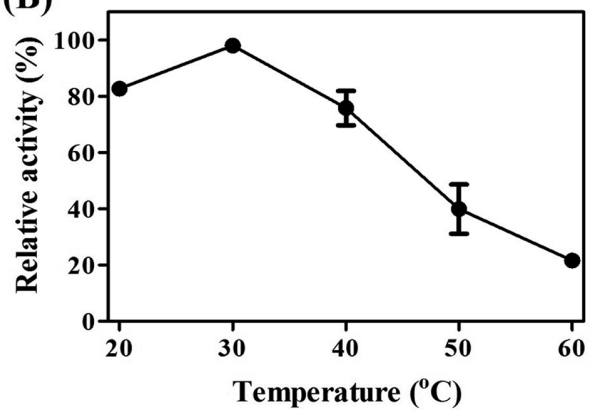

Fig. 4 Influence of $\mathrm{pH}$ (A) and temperature (B) on the activity of the crude enzyme isolated from Chryseobacterium sp. P1-3 strain.

Table 1 Optimum $\mathrm{pH}$ and temperature of other keratin-degrading strains

\begin{tabular}{lccl}
\hline \multicolumn{1}{c}{ Strain } & Optimum temperature $\left({ }^{\circ} \mathrm{C}\right)$ & Optimum $\mathrm{pH}$ & \multicolumn{1}{c}{ Reference } \\
\hline B. subtilis MTCC $(9102)$ & 40 & 6.0 & (Balaji et al., 2008) \\
B. subtilis KS-1 & 60 & 7.0 & (Suh and Lee, 2001) \\
Streptomyces sp. S.K ${ }_{1-02}$ & 70 & 10.0 & (Letourneau et al., 1998) \\
Microbacterium sp. kr10 & 50 & 7.5 & (Thys and Brandelli, 2006) \\
Chryseobacterium sp. kr6 & 55 & 7.5 & (Riffel et al., 2003) \\
Chryseobacterium sp. RBT & 50 & 8.6 & (Gurav and Jadhav, 2013) \\
Chryseobacterium sp. nov. L99 & 40 & 9.0 & (Lv et al., 2010) \\
\hline
\end{tabular}

production of keratinase, the other variables were not investigated. The enzymatic activity at $30^{\circ} \mathrm{C}$ was sufficient for the degradation of keratin. In future studies, we will perform next-generation sequencing by using the isolated P1-3 strain. We plan to identify the gene encoding keratinase gene in the near future.

Optimum pH and temperature. The influence of $\mathrm{pH}$ on the crude enzyme activity was investigated (Fig. 4A). The optimal $\mathrm{pH}$ for keratinase activity was 8.0 , and more than $80 \%$ of the enzymatic activity was retained in the $\mathrm{pH}$ range $7-9$. However, the enzyme activity decreased significantly in predominantly acidic and basic environments. The optimal temperature for the enzymatic activity was $30^{\circ} \mathrm{C}$ (Fig. $4 \mathrm{~B}$ ). At $40^{\circ} \mathrm{C}$, approximately $80 \%$ of the enzyme activity was retained, and it reduced drastically at temperatures above $50^{\circ} \mathrm{C}$. Thus, the microbial keratinase showed optimal activity in the temperature range $30-80^{\circ} \mathrm{C}$ and in the $\mathrm{pH}$ range 7-9 (Gupta and Ramnani, 2006). Keratinase isolated from Bacillus subtilis MTCC (9102) showed optimal activity at a temperature of $40^{\circ} \mathrm{C}$ and $\mathrm{pH} 6.0$, while keratinase isolated from $B$. subtilis KS-1 showed optimal activity at a temperature of $60^{\circ} \mathrm{C}$ and $\mathrm{pH}$ 7.0. The keratinase derived from Streptomyces sp. S.K $\mathrm{K}_{1-02}$ showed optimal activity at a temperature of $70^{\circ} \mathrm{C}$ and $\mathrm{pH} 10.0$; the keratinase derived from Microbacterium sp. kr10 showed optimal activity at a temperature of $50^{\circ} \mathrm{C}$ and $\mathrm{pH} 7.5$; and the keratinase isolated from the Chryseobacterium species showed optimal activity in the temperature range $40-55^{\circ} \mathrm{C}$ and in the $\mathrm{pH}$ range 7.5-9.0 (Table 1). Upon comparing the reference strains with the isolated P1-3 strain, it was evident that the optimum $\mathrm{pH}$ was quite similar. However, the optimal temperature was higher in the reference strains than in the isolated P1-3 strain. Using mesophilic enzymes and microbes to the industrial process is more beneficial than the corresponding thermophilic enzymes and microbes owing to the low energy consumption of the former (Kumar et al., 2008). This enzyme could be considered as industrially and commercially important biomolecule, because it has advantages of reproducibility under normal laboratory conditions and mild enzymatic reaction conditions of $\mathrm{pH}$ and temperature.

Acknowledgments This research was supported by the Technology Development Program for Bio-industry, Ministry for Agriculture Food and Rural Affairs, Republic of Korea.

\section{References}

Bach E, Cannavan FS, Duarte FR, Taffarel JA, Tsai SM, and Brandelli A (2011) Characterization of feather-degrading bacteria from Brazilian soils. Int Biodeterior Biodegrad 65, 102-7.

Balaji S, Kumar MS, Karthikeyan R, Kumar R, Kirubanandan S, Sridhar R et al. (2008) Purification and characterization of an extracellular keratinase from a hornmeal-degrading Bacillus subtilis MTCC (9102). World $J$ Microb Biot 24, 2741-5.

Bockle B, Galunsky B, and Muller R (1995) Characterization of a keratinolytic serine proteinase from Streptomyces pactum DSM 40530. Appl Environ Microbiol 61, 3705-10.

Brandelli A (2008) Bacterial keratinases: useful enzymes for bioprocessing agroindustrial wastes and beyond. Food Bioprocess Tech 1, 105-16.

Chaudhari PN, Chaudhari BL, and Chincholkar SB (2013) Iron containing keratinolytic metallo-protease produced by Chryseobacterium gleum. Process Biochem 48, 144-51.

Corrêa APF, Daroit DJ, and Brandelli A (2010) Characterization of a keratinase produced by Bacillus sp. P7 isolated from an Amazonian environment. Int Biodeterior Biodegrad 64, 1-6.

Cortezi M, Cilli E, and Contiero J (2008) Bacillus amyloliquefaciens: a new keratinolytic feather-degrading bacteria. Curr Trends Biotechnol Pharm 2, 170-7. 
Felsenstein J (1985) Confidence limits on phylogenies: an approach using the bootstrap. Evolution 39, 783-91.

Gradišar H, Kern S, and Friedrich J (2000) Keratinase of Doratomyces microsporus. Appl Microbiol Biotechnol 53, 196-200.

Gupta R and Ramnani P (2006) Microbial keratinases and their prospective applications: an overview. Appl Microbiol Biotechnol 70, 21-33.

Gurav RG and Jadhav JP (2013) Biodegradation of keratinous waste by Chryseobacterium sp. RBT isolated from soil contaminated with poultry waste. J Basic Microbiol 53, 128-35.

Hugo CJ, Segers P, Hoste B, Vancanneyt M, and Kersters K (2003) Chryseobacterium joostei sp. nov., isolated from the dairy environment. Int J Syst Evol Microbiol 53, 771-7.

Jeong J-H, Jeon Y-D, Lee O-M, Kim J-D, Lee N-R, Park G-T et al. (2010) Characterization of a multifunctional feather-degrading Bacillus subtilis isolated from forest soil. Biodegradation 21, 1029-40.

Joshi SG, Tejashwini M, Revati N, Sridevi R, and Roma D (2007) Isolation, identification and characterization of a feather degrading bacterium. Int $J$ Poult Sci 6, 689-93.

Kim O-S, Cho Y-J, Lee K, Yoon S-H, Kim M, Na H et al. (2012) Introducing EzTaxon-e: a prokaryotic 16S rRNA gene sequence database with phylotypes that represent uncultured species. Int J Syst Evol Microbiol 62, 716-21.

Kumar AG, Swarnalatha S, Gayathri S, Nagesh N, and Sekaran G (2008) Characterization of an alkaline active-thiol forming extracellular serine keratinase by the newly isolated Bacillus pumilus. J Appl Microbiol 104, 411-9.

Letourneau F, Soussotte V, Bressollier P, Branland P, and Verneuil B (1998) Keratinolytic activity of Streptomyces sp. S. K1-02: a new isolated strain. Lett Appl Microbiol 26, 77-80.

Lowry OH, Rosebrough NJ, Farr AL, and Randall RJ (1951) Protein measurement with the Folin phenol reagent. J Biol Chem 193, 265-75.

Lv L-X, Sim M-H, Li Y-D, Min J, Feng W-H, Guan W-J et al. (2010) Production, characterization and application of a keratinase from Chryseobacterium L99 sp. nov. Process Biochem 45, 1236-44.

Macedo AJ, Da Silva WOB, Gava R, Driemeier D, Henriques JaP, and Termignoni C (2005) Novel keratinase from Bacillus subtilis S14 exhibiting remarkable dehairing capabilities. Appl Environ Microbiol 71, 594-6.

Nam G-W, Lee D-W, Lee H-S, Lee N-J, Kim B-C, Choe E-A et al. (2002) Native-feather degradation by Fervidobacterium islandicum AW-1, a newly isolated keratinase-producing thermophilic anaerobe. Arch Microbiol 178, $538-47$.

Onifade A, Al-Sane N, Al-Musallam A, and Al-Zarban S (1998) A review: potentials for biotechnological applications of keratin-degrading microorganisms and their enzymes for nutritional improvement of feathers and other keratins as livestock feed resources. Bioresour Technol
66, $1-11$.

Riessen S and Antranikian G (2001) Isolation of Thermoanaerobacter keratinophilus sp. nov., a novel thermophilic, anaerobic bacterium with keratinolytic activity. Extremophiles 5, 399-408.

Riffel A, Brandelli A, Bellato CDM, Souza GHMF, Eberlin MN, and Tavares FCA (2007) Purification and characterization of a keratinolytic metalloprotease from Chryseobacterium sp. kr6. J Biotechnol 128, 693703.

Riffel A, Lucas F, Heeb P, and Brandelli A (2003) Characterization of a new keratinolytic bacterium that completely degrades native feather keratin. Arch Microbiol 179, 258-65.

Saitou N and Nei M (1987) The neighbor-joining method: a new method for reconstructing phylogenetic trees. Mol Biol Evol 4, 406-25.

Shih JCH (1993) Recent Development in Poultry Waste Dizgestion and Feather Utilization-A Review. Poult Sci 72, 1617-20.

Suh HJ and Lee HK (2001) Characterization of a keratinolytic serine protease from Bacillus subtilis KS-1. J Protein Chem 20, 165-9.

Tamura K, Peterson D, Peterson N, Stecher G, Nei M, and Kumar S (2011) MEGA5: molecular evolutionary genetics analysis using maximum likelihood, evolutionary distance, and maximum parsimony methods. Mol Biol Evol 28, 2731-9.

Thys R and Brandelli A (2006) Purification and properties of a keratinolytic metalloprotease from Microbacterium sp. J Appl Microbiol 101, 1259 68.

Vandamme P, Bernardet J-F, Segers P, Kersters K, and Holmes B (1994) NOTES: New Perspectives in the Classification of the Flavobacteria: Description of Chryseobacterium gen. nov., Bergeyella gen. nov., and Empedobacter nom. rev. Int J Syst Bacteriol 44, 827-31.

Venter H, Osthoff G, and Litthauer D (1999) Purification and Characterization of a Metalloprotease from Chryseobacterium indologenes Ix9a and Determination of the Amino Acid Specificity with Electrospray Mass Spectrometry. Protein Expression Purif 15, 282-95.

Wang SL, Hsu WT, Liang TW, Yen YH, and Wang CL (2008) Purification and characterization of three novel keratinolytic metalloproteases produced by Chryseobacterium indologenes TKU014 in a shrimp shell powder medium. Bioresour Technol 99, 5679-86.

Wang X and Parsons CM (1997) Effect of processing systems on protein quality of feather meals and hog hair meals. Poult Sci 76, 491-6.

Weisburg WG, Barns SM, Pelletier DA, and Lane DJ (1991) 16S ribosomal DNA amplification for phylogenetic study. J Bacteriol 173, 697-703.

Weon H-Y, Kim B-Y, Yoo S-H, Kwon S-W, Stackebrandt E, and Go S-J (2008) Chryseobacterium soli sp. nov. and Chryseobacterium jejuense sp. nov., isolated from soil samples from Jeju, Korea. Int J Syst Evol Microbiol 58, 470-3.

Zerdani I, Faid M, and Malki A (2004) Feather wastes digestion by new isolated strains Bacillus sp. in Morocco. Afr J Biotechnol 3, 67-70. 